\title{
Amphibian and Reptile Survey on Montana Refuges: 1996
}

\author{
A Report to: \\ US Fish and Wildlife Service \\ Montana Field Office \\ P.O. Box 10023 \\ Helena, MT 59626 \\ Benton Lake National Wildlife Refuge \\ 922 Bootlegger Trail \\ Great Falls, MT 59404-6133 \\ Bowdoin National Wildlife Refuge \\ HC 65, Box 5700 \\ . Malta, MT 59538 \\ Charles M. Russell National Wildlife Refuge \\ P.O. Box 110 \\ Lewistown, MT 59457 \\ Submitted by \\ PAUL HENDRICKS and JAMES D. REICHEL \\ March 1998 \\ Montana Natural Heritage Program \\ 1515 East Sixth Avenue \\ P.O. Box 201800 \\ Helena, MT 59620-1800
}


๑ 1998 Montana Natural Heritage Program

This document should be cited as follows

Hendricks, P., and J. D. Reichel. 1998. Amphibian and reptile survey on Montana refuges: 1996. Montana Natural Heritage Program. Helena, MT. 19 pp. 


\begin{abstract}
A total of 37 site surveys were made between May and July 1996 on lands administered by the U.S. Fish and Wildlife Service in north-central Montana. Localized areas across the entire region were covered in the survey; included during the 1996 inventory were 9 Waterfowl Protection Areas (WPAs) and 6 National Wildlife Refuge (NWR's). Most were surveys, usually made by 1 individual, of ponds, lakes, seeps, streams or other wetlands. Each survey took 6-120 personminutes and consisted of a thorough search of the wetland perimeter and netting of near shore aquatic habitats for adults, eggs, larvae, and tadpoles. Stream sampling, when conducted, was done by hand and dipnet. Seeps were checked by rolling over rocks and logs in and near wet. areas. In addition to surveys, sightings were made from road kills, vocal identifications or fortuitous sightings by other reliable individuals. An additional 132 wetlands (permanent or temporary) were surveyed, and 36 opportunistic observations were made, in the region encompassing the USFWS units.

Five amphibian species and three reptile species were detected during the 1996 site surveys. Amphibian and reptile species, and number of WPA/NWR's ("units") where detected, included Tiger Salamander (Ambystoma tigrimum) at 3 units, Western Chorus Frog (Pseudacris triseriata) at 11 units, Woodhouse's Toad (Bufo woodhousii) at 1 unit, Great Plains Toad (Bufo cognatus) at 1 unit, Northern Leopard Frog (Rana pipiens) at 1 unit, Painted Turtle (Chrysemys picta) at 3 units, Common Garter Snake (Thamnophis sirtalis) at 1 unit, and Plains Garter Snake (Thamnophis radix) at 2 units. Opportunistic encounters added three species detected on USFWS units in 1996: Western Hognose Snake (Heterodon nasicus), Racer (Coluber constrictor), Gopher Snake (Pituophis catenifer). Other wetland surveys and opportunistic encounters in the region in 1996 included three additional species (one amphibian and two snake species) not recorded at the USFWS units during the inventory: Plains Spadefoot (Scaphiopus bombifrons), Western Terrestrial Garter Snake (Thamnophis elegans), Western Rattlesnake (Crotalus viridis).

Greatest detected diversity was on or near Charles M. Russell National Wildlife Refuge (CMR), which included all species encountered in 1996 except Plains Garter Snake; this species was detected on the adjacent UL Bend NWR, however, and probably occurs on the CMR as well. Almost 33\% of all site surveys during the 1996 inventory were on or near the CMR, which is the largest unit on which site surveys were conducted. No amphibians or reptiles were noted on three USFWS units, one species on five units, two species on 4 units, three species on one unit, and seven species on one unit. For all (37) site surveys, no species were detected on 12, one species on 15 , two species on 6 , three species on 3 , and four species on 1.

Historical records and earlier surveys indicated the presence of four additional species on USFWS lands not encountered during the 1996 surveys: Plains Spadefoot, Spiny Softshell (Trionyx spiniferus), Short-horned Lizard (Phrynosoma douglasi), Western Rattlesnake.
\end{abstract}




\section{TABLE OF CONTENTS}

ABSTRACT $\ldots \ldots \ldots \ldots \ldots \ldots \ldots \ldots \ldots \ldots \ldots \ldots \ldots \ldots \ldots \ldots \ldots \ldots \ldots \ldots \ldots \ldots$.iii ACKNOWLEDGMENTS $\ldots \ldots \ldots \ldots \ldots \ldots \ldots \ldots \ldots \ldots \ldots \ldots \ldots \ldots, \mathrm{v}$ INTRODUCTION $\ldots \ldots \ldots \ldots \ldots \ldots \ldots \ldots \ldots \ldots \ldots \ldots \ldots \ldots \ldots \ldots \ldots \ldots \ldots \ldots$

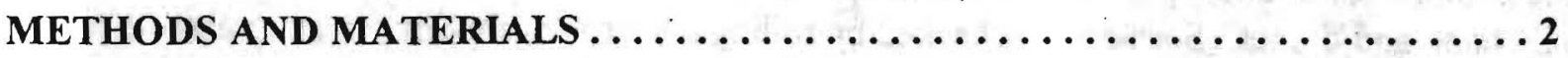

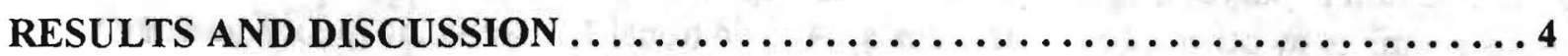

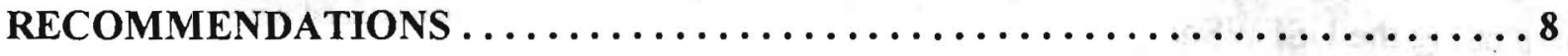

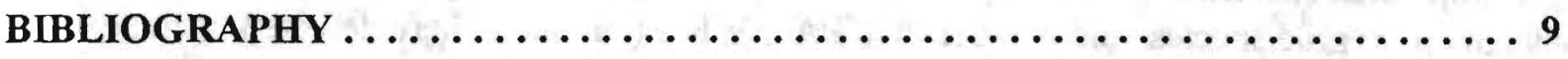
APPENDIX 1. SITES SURVEYED. $\ldots \ldots \ldots \ldots \ldots \ldots \ldots \ldots \ldots \ldots \ldots \ldots \ldots \ldots$ APPENDIX 2. SPECIES DETECTED ON SURVEYS $\ldots \ldots \ldots \ldots \ldots \ldots \ldots \ldots$ 


\section{ACKNOWLEDGMENTS}

We thank K. Werner for conducting some of the site surveys, M. and J. Miller for data entry, $\mathrm{S}$. Lee-Schadde and $\mathrm{C}$. Jones for making the maps. Financial support for the project came from the U. S. Fish and Wildlife Service (Montana Field Office) and the Montana Natural Heritage Program (Montana State Library, Natural Resources Information System and The Nature Conservancy).

Museum records were received from: American Museum of Natural History, Academy of Natural Science, Brigham Young University, California Academy of Science, Carnegie Museum, University of Puget Sound Museum, Field Museum of Natural History, Glacier National Park Museum, Illinois Natural History Survey, University of Kansas, Los Angeles County Museum, Louisiana State University Museum of Zoology, Museum of Comparative Zoology - Harvard, Milwaukee Public Museum, Montana State University Museum, Michigan State University Museum, North Carolina State Museum of Natural History, Northern Louisiana University Museum, University of Colorado Museum, University of Georgia Museum of Natural History, University of Idaho Museum, University of Michigan Museum, University of South Dakota, United States National Museum of Natural History, University of Texas - Arlington, University of Texas - El Paso, and Peabody Museum - Yale. Most museum data were received with the help of Dr. Charles Peterson, Idaho State University, Pocatello.

Jim Reichel died prior to the completion of this report. Jim was instrumental in organizing and conducting a series of amphibian and reptile surveys across Montana, the first comprehensive effort in three decades. This report represents one of a series of projects that contribute to a baseline inventory of the entire state. 


\section{INTRODUCTION}

Many amphibians are apparently declining in the western U.S. and world-wide. Acid rain, ozone depletion, pollution by toxic chemicals and heavy metals, predation and/or competition by exotic species, habitat alteration, climatic changes, disease, immune system problems, and combinations of several of these factors have all been suggested as possible causes (Corn and Fogelman 1984, Phillips 1990, Yoffe 1992).

Preliminary data indicate that the Northern Leopard Frog (Rana pipiens) has disappeared over much of its former range in western Montana and is declining in at least some areas of eastern Montana. Status and population trends of several toad species (Bufo spp.) are unknown, although declines of the Western Toad (Bufo boreas) have recently been reported in northern Idaho (C. Peterson pers. comm.), northwestern Montana (Werner and Reichel 1994), Yellowstone National Park (Koch and Peterson 1995) and Colorado (Carey 1993). Land-use practices, such as large-scale logging, continue to be detrimental to resident herpetofauna in some regions of the western U.S. (Bury et al. 1991), while the impacts of grazing on amphibians and reptiles and their habitats remain poorly studied and understood. Heavy grazing in and around breeding waters may also negatively impact amphibians and reptiles living in riparian and wetland sites by 1) eliminating emergent vegetation necessary for egg and larval survival, 2) lowering water quality, especially causing high siltation levels, 3 ) soil compaction and trampling of turtle eggs, and 4) trampling of eggs, larvae and adults. Additionally, "improving" seeps and springs for livestock watering may make them unavailable to breeding amphibians.

The Montana Natural Heritage Program currently (1997) lists five amphibian and five reptile species as Animal Species of Special Concern. Of these, Canadian Toad (Bufo hemiophrys), Northern Leopard Frog (Rana pipiens), Snapping Turtle (Chelydra serpentina), Spiny Softshell (Trionyx spiniferus), Western Hognose Snake (Heterodon nasicus) and Milk Snake (Lampropeltis triangulum) occur or potentially occur in the region of focus in this report. 


\section{METHODS AND MATERIALS}

Six National Wildlife Refuges (Thibadeau, Creedman Coulee, Black Coulee, Bowdoin, Charles M. Russell, UL Bend) and nine Waterfowl Protection Areas (Foster Creek, Jarina, Kingsbury, Korsbeck, Holm, Brown, Webb, Dyrdahl, Pearse) in north-central Montana were surveyed during the 1996 inventory.

Historical locations of amphibians and reptiles were recorded from literature (see Bibliography) and museum specimen records. Records were received from over 20 major museums which have computerized their collections in North America (see Acknowledgments). Locations derived from these sources have been entered into a database and digitized. Distribution maps were created using survey and sighting data and historical records, including specimens.

Survey sites were chosen based on 3 criteria: 1) high priority sites as determined by the USFWS; 2) location of streams, seeps and wetlands on topographic maps; and 3) accessibility of the wetlands by roads. Based on the above, 3-6 sites were chosen daily for surveys. Six minutes to 2 hours were spent at each site, depending upon the size of the area and what was found. Initially, the entire shoreline, or a major part thereof, was searched by walking slowly along the edge and up into the surrounding vegetation, including rolling over rocks and logs. At regular intervals, the aquatic habitat was sampled for tadpoles or larvae using dipnets. If the initial sampling showed amphibian/reptile species present, further effort was expended in order to get some idea of abundance and distribution.

An attempt was made to capture at least the first few individuals of a species seen at a survey site. The species name was recorded along with developmental stage and sex (if possible); the animals were then released. On occasion, representative samples of the more common species in an area were preserved for permanent museum records and will be deposited at the Idaho State University Museum. Water temperature, air temperature, and a general description of the area were recorded. Standard data sheets were used during this project; the amphibian survey data sheet was developed by U.S. Fish and Wildlife Service and is used extensively by a variety of researchers in the western U.S. Much site-specific data was gathered during these surveys; not all data has been analyzed or is presented in this report, but is available from the Montana Natural Heritage Program. 
Herp Survey Locations

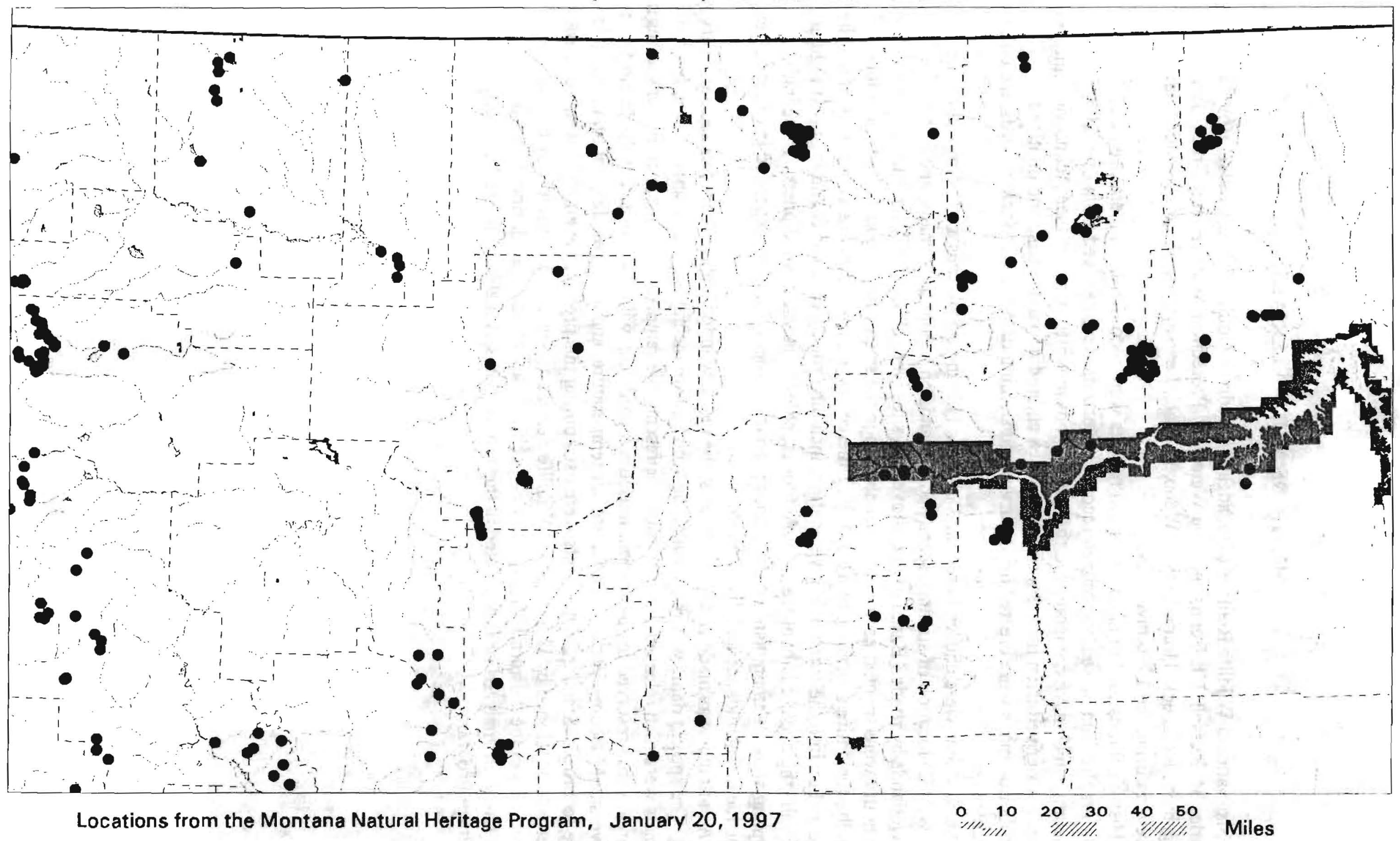




\section{RESULTS AND DISCUSSION}

\section{General Summary}

A total of 37 sites was surveyed in May through July 1996 of which 25 had one or more amphibian or reptile species present (Appendix 1). Localized areas across the entire region were covered in the inventory; included were 9 Waterfowl Protection Areas (WPAs) and 6 National Wildlife Refuge (NWR's). Although no species were found at 12 sites, their absence may have been due to the time of day, weather conditions, or other factors at the time of sampling.

Five amphibian species and three reptile species were detected during the 1996 site surveys on USFWS administered lands (Appendix 2). Amphibian and reptile species, and number of WPA/NWR's ("units") where detected, included Tiger Salamander (Ambystoma tigrinum) at 3 units, Western Chorus Frog (Pseudacris triseriata) at 11 units, Woodhouse's Toad (Bufo woodhousii) at 1 unit, Great Plains Toad (Bufo cognatus) at 1 unit, Northern Leopard Frog (Rana pipiens) at 1 unit, Painted Turtle (Chrysemys picta) at 3 units, Common Garter Snake (Thamnophis sirtalis) at 1 unit, and Plains Garter Snake (Thamnophis radix) at 2 units.

Greatest detected diversity was on or near Charles M. Russell National Wildlife Refuge (CMR), which included all species encountered in 1996 except Plains Garter Snake; this species was detected on the adjacent UL Bend NWR, however, and probably occurs on the CMR as well Almost $33 \%$ of all site surveys during the 1996 inventory were on or near the CMR, which is the largest unit on which site surveys were conducted. No amphibians or reptiles were noted on three USFWS units, one species on five units, two species on 4 units, three species on one unit, and seven species on one unit. No species were detected on 12 , one species on 15 , two species on 6 , three species on 3 , and four species on 1 of the site surveys.

Opportunistic sightings on USFWS units in 1996 added three species not reported during site surveys: Gopher Snake (Pituophis catenifer), Western Hognose Snake (Heterodon nasicus), Racer (Coluber constrictor). Historical records and earlier surveys indicated the presence of four additional species on USFWS lands not encountered during the 1996 inventory: Plains Spadefoot (Scaphiopus bombifrons), Spiny Softshell (Trionyx spiniferus), Short-horned Lizard (Phrynosoma douglasi), Western Rattlesnake (Crotalus viridis).

In addition to the 37 site surveys on USFWS units, there were 132 site surveys in 1996 on other public lands (mostly BLM) in the region, and 36 opportunistic sightings (i.e. road kills, chance observations) for which data are available and the sightings considered reliable. Survey results included Tiger Salamander at 3 sites, Western Chorus Frog at 32 sites, Northern Leopard Frog at 10 sites, Plains Spadefoot at 2 sites, Painted Turtle at 5 sites, Plains Garter Snake at 8 sites and Western Terrestrial Garter Snake (Thamnophis elegans) at 1 site. These surveys and opportunistic encounters in 1996 included three species not recorded at the USFWS units during the 1996 inventory: Plains Spadefoot, Western Terrestrial Garter Snake, Western Rattlesnake.

The following accounts are organized by USFWS unit, beginning with eight NWR's (including two not visited in 1996) and followed by nine WPA's. Included in each account are a description of the 1996 survey results and a summary of species previously documented from each unit and in the MTNHP database in Helena. 


\section{USFWS Unit Accounts}

Black Coulee National Wildlife Refuge. One survey was conducted at this unit on 10 July. Two tadpoles of the Western Chorus Frog, confirming breeding, were sampled during 30 sweeps.

There are no additional records of amphibians or reptiles for this refuge in the MTNHP database.

Benton Lake National Wildlife Refuge. No surveys were conducted on this refuge in 1996. There are records of four species (Tiger Salamander, Western Chorus Frog, Painted Turtle, Plains Garter Snake) for this refuge in the MTNHP database.

Bowdoin National Wildlife Refuge. Four surveys were conducted at this unit, three on 20 June and one on 25 July. Two species were noted, one each on two 20 June surveys: one adult Painted Turtle was seen in the Lakeside Unit near Dry Lake Canal, and Western Chorus Frog (3 adults and about 100 tadpoles) was observed in Goose Island Pond. Two other species were encountered in 1996. Two Gopher Snakes and one Racer were seen near the maintenance shop on 20 June. There are records of two additional species (Tiger Salamander, Western Rattlesnake) for this refuge in the MTNHP database.

Charles M. Russell National Wildlife Refuge. Twelve surveys were conducted on or near this refuge between 13-18 June. A total of seven species was detected at nine sites: Tiger Salamander (larvae) at 1 site, Western Chorus Frog at 8 sites (adults at 5 sites, tadpoles at 4 sites), Woodhouse's Toad at 3 sites (adults at 2 sites, tadpoles at 1 site), Great Plains Toad at 2 sites (adults at 1 site, a juvenile at 1 site), Northern Leopard Frog at 2 sites ( 1 adult at each), Painted Turtle (one adult) at 1 site, Common Garter Snake (one adult) at 1 site. Woodhouse's Toad was noted at two other sites in 1996: one adult near the mouth of Sand Creek on 14 June, one adult between the N \& S Forks of Rock Creek. Three additional species were encountered in 1996. Western Hognose Snake was seen at 2 sites (Rd. $2012 \mathrm{mi}$. E of Hwy 191 on 13 June, and $2 \mathrm{mi}$. S of Rock Creek Marina on 16 June). Gopher Snake was seen at 2 sites (Rd. $2016 \mathrm{mi}$. E of Hwy 191 on 13 June, and Knox Ridge Rd. $1 \mathrm{mi}$. W of Hwy 191 on 14 June). Racer was seen at 1 site (Rd. $2172 \mathrm{mi}$. S of Rock Creek Marina on 16 June). There are records of two additional species (Spiny Softshell, Western Rattlesnake) for this refuge in the MTNHP database.

Creedman Coulee National Wildlife Refuge. One survey was conducted at this unit on 3 June. At least ten adult Western Chorus Frogs were heard calling; no tadpoles were captured in 30 sweeps. There are no additional records of amphibians or reptiles for this refuge in the MTNHP database.

Thibadeau National Wildlife Refuge. This site was visited on 3 June, but only a small part (not surveyed) held any water and was a flooded hayfield; nearby Grassy Lake was plowed and dry. There are no records of amphibians or reptiles for this refuge in the MTNHP database. 
UL Bend National Wildlife Refuge. Two surveys were conducted on this refuge on 19 June. A total of three species was detected: Western Chorus Frogs (tadpoles) at 2 sites, Painted Turtle (1 adult, 1 juvenile) at 1 site, Plains Garter Snake at 2 sites ( 5 and 4 adults, respectively). There are no additional records of amphibians or reptiles for this refuge in the MTNHP database.

War Horse National Wildlife Refuge. No surveys were conducted on this refuge in 1996. There are records of three species (Western Chorus Frog, Plains Spadefoot, Northern Leopard Frog) for this refuge in the MTNHP database.

Brown Waterfowl Protection Area. One survey was conducted at this WPA on 1 June. One species, Western Chorus Frog (about 50 calling adults), was observed; no tadpoles were caught in 15 sweeps. There are no additional records of amphibians or reptiles for this WPA in the MTNHP database.

Dyrdahl Waterfowl Protection Area. One survey was conducted at this WP.A on 11 July. One species, Western Chorus Frog ( 3 tadpoles), was captured in 50 sweeps of three potholes. There are no additional records of amphibians or reptiles for this WPA in the MTNHP database.

Foster Creek Waterfowl Protection Area. One survey was conducted at this WPA on 22 July. No amphibian or reptile species were encountered. There are no records of amphibians or reptiles for this WPA in the MTNHP database.

Holm Waterfowl Protection Area. Two surveys were conducted at this WPA on 4 June. Two species were noted: Western Chorus Frog (about 50 calling adults, no tadpoles in 20 sweeps) was noted at Holm Reservoir, Western Chorus Frog (about 100 adults, no tadpoles in 20 sweeps) and Plains Garter Snake ( 1 adult) were noted at McLaren Reservoir. There are no additional records of amphibians or reptiles for this WPA in the MTNHP database.

Jarina Waterfowl Protection Area. Two surveys were conducted at this WPA on 31 May. One species was noted: Western Chorus Frog ( 5 calling adults, no tadpoles) was noted at an unnamed lake $0.5 \mathrm{mi}$. ENE of NW Howe Lake. No species were noted in NE Howe Lake. There are no additional records of amphibians or reptiles for this WPA in the MTNHP database.

Kingsbury Waterfowl Protection Area. Four surveys were conducted at this WPA on 3 June. A total of two species was detected on 2 surveys: Tiger Salamander (larvae and eggs) at 2 sites, Western Chorus Frogs ( 4 calling adults) at 1 site. There are records of four additional amphibian and reptile species (Short-horned Lizard, Gopher Snake, Racer, Western Rattlesnake) for this WPA in the MTNHP database.

Korsbeck Waterfowl Protection Area. Four surveys were conducted at this WPA on 4 June. A total of two species was detected on 3 surveys: Tiger Salamander (1 larvae in Pond 1) at 1 site, Western Chorus Frogs at 3 sites ( 8 calling adults and 90 tadpoles in Pond 1, 60 tadpoles in Pond 2, 185 tadpoles in East Pond). There are no additional records of amphibians or reptiles for this 
WPA in the MTNHP database.

Pearse Waterfowl Protection Area. One survey was conducted at this WPA on 25 July. No amphibian or reptile species were encountered. There are no records of amphibians or reptiles for this WPA in the MTNHP database.

Webb Waterfowl Protection Area. One survey was conducted at this WPA on 11 July. No amphibian (50 sweeps) or reptile species were encountered. There are no records of amphibians or reptiles for this WPA in the MTNHP database. 


\section{RECOMMENDATIONS}

1) Incidental sightings of amphibians and reptiles from the USFWS units should be recorded and forwarded to the Natural Heritage Program. Of particular interest are all observations and locations of breeding amphibians (tadpoles and/or eggs) and all reptiles. Use Reichel and Flath (1995) as an identification aid. Vouchers of amphibian tadpoles can be sent to the Natural Heritage program for identification.

2) Due to the time constraints and the large area covered in the 1996 survey, it should not be regarded as a definitive index of all the amphibians and reptiles or their presence on the USFWS units. The secretive habits of many amphibians and reptiles, and our lack of knowledge regarding their reproductive behavior make it difficult to assess their overall status. We recommend that additional surveys be conducted.

3) When more breeding locations for amphibians are known, long-term monitoring of typical marsh-pond habitats should be set up at several sites in order to evaluate relative numbers and breeding success of the more common species: Tiger Salamander, Western Chorus Frog, Woodhouse's Toad, Northern Leopard Frog, Plains Garter Snake, and Common Garter Snake. Particular attention needs to be given to any toad and Northern Leopard Frog breeding sites found. Life history and ecology of the amphibians in Montana is poorly known for most species. Long-term monitoring will give us information on timing of breeding and habitat requirements needed for successful reproduction. 


\section{BIBLIOGRAPHY}

Baxter, G. T. and M. D. Stone. 1985. Amphibians and reptiles of Wyoming. Wyoming Game and Fish Department. Cheyenne, Wyoming. 137 pp.

Bergeron, D. No date. Terrestrial wildlife survey, Coal Creek Mine Area, Montana, 1977-1978. West. Tech. \& Eng., Inc., Helena.

Bernard, S. R. and K. F. Brown. 1977. Distribution of mammals, reptiles, and amphibians by

BLM physiographic regions and A. W. Kuchler's associations for the eleven Western States.

Black, J. H. 1967. A blue leopard frog from Montana. Herpetologica 23 (4):314-315.

Black, J. H. 1969. The frog genus Rana in Montana. Northwest Sci. 43:191-195.

Black, J. H. 1970. Amphibians of Montana. Mont. Fish \& Game Dept., Pub. No. 1 of Animals of Montana Series.

Black, J. H. 1970. Some aspects of the distribution, natural history and zoogeography of the toad genus Bufo in Montana. M.S. thesis, University of Montana, Missoula.

Black, J. H. 1970. Turtles of Montana. Montana Wildlife, Animals of Montana Series 2:26-32.

Black, J. H. 1970. Unusual forms of boreal toads Bufo boreas (Amphibia: Bufonidae) in Glacier National Park, Montana. Proc. Okla. Acad. Sci 50: 127-128.

Black, J. H. 1971. The toad genus Bufo in Montana. Northwest Sci. 45: 156-162.

Black, J. H. and A. M. Bragg. 1968. New additions to the herpetofauna of Montana.

Herpetologica 24:247.

Black, J. H. and R. B. Brunson. 1971. Breeding behavior of the boreal toad Bufo boreas boreas

(Baird and Girard) in western Montana. Great Basin Nat. 31: 109-113.

Black, J. H. and V. Craig (eds.). 1970. Amphibians of Montana. Montana Wildlife, Animals of Montana Series 1:1-32.

Bragg, A. N. 1940. Observations on the ecology and natural history of Anura. I. Habits, habitat and breeding of Bufo cognatus say. Amer. Nat. 74:322-438.

Breckenridge, W. J. and J. R. Tester. 1961. Growth, local movements, and hibernation of the Manitoba toad, Bufo hemiophrys. Ecology 42:637-646.

Brunson, R. B. 1952. Recent collections of Bufo boreas boreas from western Montana. Proc. Montana Acad. Sci. 11:17-19.

Brunson, R. B. 1955. Check list of the amphibians and reptiles of Montana. Proc. Mont. Academy Sci. 15:27-29.

Brunson, R. B. and H. A. Demaree. 1951. The herpetology of the Mission Mountains, Montana. Copeia 1951:306-308.

Bureau of Land Management. 1982. Bloomfield - North Fork baseline inventories - wildlife. Miles City, MT.

Bury, R. B., P. S. Corn, K. B. Aubry, F. F. Gilbert and L. L. C. Jones. 1991. Aquatic amphibian communities in Oregon and Washington. U.S.D.A. For. Serv., Pac. NW Res. Station Gen. Tech Rep. PNW-GTR-285:353-362.

Camp, Dresser, and McKee, Inc. 1981. Anaconda Stillwater project 12-month environmental baseline report. Tech. Rpt. for Anaconda Copper Co.

Carey, C. 1993. Hypothesis concerning the causes of the disappearance of boreal toads from the mountains of Colorado. Conservation Biology 7(2):355-362. 
Conant, R. 1975. A field guide to reptiles and amphibians of eastern and central North America. Second edition. Houghton Mifflin Co., Boston. xvii +429 pp.

Corn, P. S. No Date. Comment on the occurrence of Pseudacris clarki in Montana. Bull. Chi. Herp. Soc. 15(3):77-78.

Corn, P. S. and J. C. Fogelman. 1984. Extinction of montane populations of northern leopard frog (Rana pipiens) in Colorado. J. Herpetol. 18:147-152.

Craig, V. No date. The Axolotl "Walking Fish." Montana Outdoors? 2 pp.

Davis, C. V. and S. E. Weeks. 1963. Montana Snakes. Montana Dept. of Fish and Game, Helena, MT, pp.1-10.

Dood, A. R. 1980. Terry Badlands nongame survey and inventory: final report. Montana Department of Fish, Wildlife, and Parks BLM Contract \#YA-512-CT8-217. 70 pp.

Econ, Inc. 1974. Terrestrial wildlife inventory for the Lame Jones and Ismay coal lease tracts. Tech. Rpt.

Ernst, C. H. 1971. CHRYSEMYS PICTA. Cat. Am. Amph. Rep. 106.1-106.4.

Ernst, C. H., J. E. Lovich, and R. W: Barbour. 1994. Turtles of the United States and Canada. Smithsonian Institution Press, Washington, D.C. 578 pp.

Farmer, P. J. and K. Burgess. 1983. Jardine area baseline terrestrial wildlife study, May 15, 1981-May 15, 1982, for Homestake Mining Co. West. Tech. Eng., Helena.

Farmer, P. J. and K. Burgess. 1984. Jardine area baseline terrestrial wildlife study. West. Tech. \& Eng., Helena.

Farmer, P. J. No date. Terrestrial wildlife survey, Pearl area, Montana, June, 1976 - June, 1977. Westech, Inc., Helena, MT.

Farmer, P. J., S. B. Heath, D. J. Bergeron and K. L. Scow. 1985. Montana Tunnels project-baseline terrestrial wildlife study. Westech, Inc., Helena, MT. for Centennial Minerals, Inc.

Finch, D. M. 1992. Threatened, endangered, and vulnerable species of terrestrial vertebrates in the Rocky Mountain Region. USFS General Technical Rep. RM-215. 38 pp.

Fitch, H. S. 1980. THAMNOPHIS SIRTALIS. Cat. Am. Amph. Rep. 270.1-270.4.

Fitch, H. S. 1983. THAMNOPHIS ELEGANS. Cat. Am. Amph. Rep. 320.1-320.4.

Fitch, H. S. and T. P. Maslin. 1961. Occurrence of the garter snake, THAMNOPHIS SIRTALIS, in the Great Plains and Rocky Mountains. University of Kansas Publications, Museum of Natural History 13(5):289-308.

Flath, D. L. 1981. Vertebrate species of special concern. Montana Department of Fish, Wildlife, and Parks. $74 \mathrm{pp}$.

Flath, D. L. 1984. Vertebrate species of special interest or concern: mammals, birds, reptiles, amphibians, fishes. Wildlife Division, Montana Department of Fish, Wildlife, and Parks. 76 pp.

Gehlbach, F. R. 1967. AMBYSTOMA TIGRINUM. Cat. Am. Amph. Rep. 52.1-52.4.

Gibbons, J. W., S. S. Novak and C. H. Ernst. 1988. CHELYDRA SERPENTINA. Cat. Am. Amph. Rep. 420.1-420,4.

Groves, C. R. and C. Peterson. 1992. Distribution and population trends of Idaho amphibians as determined by mail questionnaire. Unpubl. Rep. Idaho Dept Fish Game, Boise, Idaho. 16 pp.

Halliday, T., and K. Adler. 1991. Encyclopedia of reptiles and amphibians. Facts on File, New York. 143 pp. 
Hammerson, G. A. 1982a. Amphibians and reptiles in Colorado. Colorado Division of Wildlife, Denver. vii $+131 \mathrm{pp}$.

Hammerson, G. A. 1982b. Bullfrog eliminating leopard frogs in Colorado? Herpetol. Rev. 13:115-116.

Hendricks, P. 1996. Geographical distribution. Thamnophis elegans vagrans. Herpetological Review 27(2):89.

Hendricks, P., and J. D. Reichel. 1996. Preliminary amphibian and reptile survey of the Ashland District, Custer National Forest: 1995. Montana Natural Heritage Program. Helena, MT. $79 \mathrm{pp}$.

Heyer, W. R., M. A. Donnelly, R. W. McDiarmid, L. C. Hayek, and M. S. Foster (eds.). 1994. Measuring and monitoring biological diversity: Standard methods for amphibians. Smithsonian Institute Press, Washington, D.C. 364 pp.

Holroyd, G. L., G. Burns and H. C. Smith (eds). 1991. Proceedings of the second endangered species and prairie conservation workshop. Provincial Museum of Alberta, Nat. Hist. Occ. Pap. 15. 284 pp.

Jellison, W. L. and J. H. Black. 1970. Tularemia in Montana and turtles of Montana. Mt. Wildlife, Nov. 1970. Mont. Fish \& Game Dept.

Kerfoot, W. C. 1968. Geographic variability of the lizard, SCELOPORUS GRACIOSUS Baird and Girard, in the eastern part of its range. Copeia 1968:139-152.

Koch, E. D., and C. R. Peterson. 1995. Amphibians and reptiles of Yellowstone and Grand Teton national parks. University of Utah Press. Salt Lake City, Utah. 188 pp.

Koonz, W. H. 1993. Amphibians in Manitoba. pp. 273-275. IN: Holroyd, G. L., H. L. Dickson,

M. Regnier and H. C. Smith (eds). Proceedings of the Third Prairie Conservation and Endangered Species Workshop. Provincial Museum of Alberta, Nat. Hist. Occ. Pap. 19. 384 $\mathrm{pp}$.

Leonard, W. P., H. A. Brown, L. L. C. Jones, K. R. McAllister and R. M. Storm. 1993.

Amphibians of Washington and Oregon. Seattle Audubon Soc., Seattle, Washington. 168 pp.

Mackie, R. J. and G. L. Dusek. 1993. A bibliography of Montana wildlife literature through 1992, DRAFT. Wildlife Management Programmatic Environmental Impact Statement Project, Montana Department of Fish, Wildlife, and Parks. 280 pp.

Marnell, L. F. 1997. Herpetofauna of Glacier National Park. Northwestern Naturalist 78:17-33. Martin, P. R. 1980. Terrestrial wildlife habitat inventory in southeastern Montana. MT Dept. of Fish, Wildlife and Parks and BLM.

Martin, P. R. 1980. Terrestrial wildlife inventory in selected coal areas of Montana. MT. Dept. of Fish, Wildlife and Parks and BLM.

Matthews, W. C. 1981. Broadus-Pumpkin Creek baseline inventory - wildlife. BLM, Miles City, MT.

McEneaney, T. and J. Jensen. 1974. The reptiles and amphibians of the Charles M. Russell National Wildlife Refuge, 1974. Unpubl. mimeo. 3 pp.

Micken, L. 1968. Some summer observations on the tiger salamander, Ambystoma tigrinum, in Blue Lake, Madison County Montana. Proc. Mont. Acad. Sci. 28:77-80.

Micken, L. 1971. Additional notes on neotenic Ambystoma tigrinum melanostictum in Blue Lake, Madison County, Montana. Proc. Mont. Acad. Sci. 31:62-64. 
Miller, J. D. 1978. Observations on the diet of Rana pretiosa, Rana pipiens, and Bufo boreas from western Montana. Northw. Sci. 52:243-249.

Montana Department of State Lands and U. S. Office of Surface Mining. 1982. Final EIS, Western Energy Company's Rosebud Mine Area C, Block 1.

Montana Department of State Lands. No date. Draft EIS, proposed plan of mining and reclamation, Zortman Mining Company and Landusky Mining Company, Phillips County, MT

Mosimann, J. E. and G. B. Rabb. 1952. The herpetology of Tiber Reservoir Area, Montana.

Copeia 1952:23-27.

Mueller, C. F. 1969. Temperature and energy characteristics of the sagebrush lizard (Sceloporus graciosus) in Yellowstone National Park. Copeia 1969:153-160.

Mueller, F. C. and R. E. Moore. 1969. Growth of the sagebrush lizard, Sceloporus graciosus, in Yellowstone National Park. Herpetologica 25:35-38.

Nelson, D. J. 1948. Lampropeltis triangulum gentilis in Montana. Herpetologica 4:170.

Nelson, D. J. 1950. Lampropeltis triangulum gentilis in Montana. Herpetologica 6:41.

Nussbaum, R. A., E. D. Brodie, Jr. and R. M. Storm. 1983. Amphibians and reptiles of the Pacific Northwest. Univ. Press of Idaho. $332 \mathrm{pp}$.

Olson-Elliott and Associates. 1979. Environmental impact of the northern tier pipeline in

Montana. Tech. Report prepared for Montana Department of Natural Resources and Conservation.

Olson-Elliott and Associates. 1980. Terrestrial wildlife inventory, Montco wildlife study area.

Tech. Report for Montco, Billings, MT.

Ortenburger, A. I. 1921. An eastern record and note on CHARINA BOTTAE (Blainville). Copeia 100:84.

Peterson, C. R., E. D. Koch and P. S. Corn. 1992. Monitoring amphibian populations in Yellowstone and Grand Teton National Parks. Unpubl. Report to Univ. Wyo. Natl. Park Serv. Res. Center. 37 pp.

Phillips, K. 1990. Where have all the frogs and toads gone? BioScience 40:422-424.

Platt, D. R. 1969. Natural history of the Hognose Snakes Heterodon platyrhinos and Heterodon nasicus. Univ. Kan. Publ., Mus. Nat. History 18(4):253-420.

Reel, S. 1989. Vest-pocket preserves. Montana Outdoors 20(2):27-29.

Reel, S., L. A. Schassberger, and W. Ruediger. 1989. Caring for our natural communities: Region 1 - threatened, endangered and sensitive species program. USDA, USFS, Northern Region, Missoula, Montana.

Reichel, J. D. 1995a. Preliminary amphibian and reptile survey of the Lewis and Clark National Forest: 1994. Montana Natural Heritage Program. Helena, MT. 92 pp.

Reichel, J. D. 1995b. Preliminary amphibian and reptile survey of the Sioux District of the Custer National Forest: 1994. Montana Natural Heritage Program. Helena, MT. 75 pp.

Reichel, J. D. and D. L. Flath. 1995. Identification guide to the amphibians and reptiles of Montana. Montana Outdoors 26(3):15-34.

Scow, K. L. 1978. Terrestrial wildlife survey, Zortman and Landusky areas, Little Rocky Mountains, MT. Tech. Rpt. for Zortman and Landusky Mining Co., Inc., by Westech, Inc. Smith, H. M. 1978. A guide to field identification Amphibians of North America. Golden Press, New York. 
Smith, H. M. and E. D. Brodie, Jr. 1982. Reptiles of North America. Golden Press, NY. 240 pp.

Stebbins, R. C. 1985. A field guide to western reptiles and amphibians. Second edition. Houghton Mifflin Co., Boston. xiv $+336 \mathrm{pp}$.

Stewart, G. R. 1977. CHARINA, C. BOTTAE. Cat. Am. Amph. Rep. 205.1-205.2.

Stuart, L. C. 1930. An extension of the range of COLUBER CONSTRICTOR MORMON (Baird and Girard). Copeia 1930:44.

Sweet, S. S. and W. S. Parker. 1990. PITUOPHIS MELANOLEUCUS. Cat. Am. Amph. Rept. 474.1-474.8.

Thompson, L. S. 1982. Distribution of Montana amphibians, reptiles, and mammals. Montana Audubon Council. $24 \mathrm{pp}$.

Timkin, R. L. and D. G. Dunlap. 1965. Ecological distribution of the two species of Bufo in southeastern South Dakota. Proc. S. D. Acad. Sci. 44:113-117.

U.S. Forest Service and Montana Department of State Lands. 1985. Jardine joint venture project.

U.S. Forest Service and Montana Department of State Lands. 1986. Jardine joint venture project, final EIS.

U.S. Geological Survey and Montana Department of State Lands. 1979. Draft, proposed mining and reclamation plan, Pearl Mine, Big Horn County, MT.

U.S. Geological Survey and Montana Department of State Lands. No date. Draft environmental statement, proposed mining and reclamation plan, Spring Creek Mine, Big Horn County, MT.

VTN. No date. Second year's analysis of terrestrial wildlife on proposed mine access and railroad routes in southern Montana and northern Wyoming, March 1979 - February 1980. Tech. Rep. prepared by VTN Wyoming, Inc., for Shell Oil Co.

Webb, R. G. 1962. North American soft-shelled turtles (Family Trionychidae). Univ. Kan. Publ., Mus. Nat. Hist. 13:429-611.

Webb, R. G. 1973. TRIONYX SPINIFERUS. Cat. Amer. Amph. and Rept. 140,1-4.

Werner, J. K. 1974. Phrynosoma douglassi brevirostre. Herp Review 5(1): 20.

Werner, K. and J. D. Reichel. 1994. Amphibian and reptile survey of the Kootenai National Forest: 1994. Montana Natural Heritage Program. 105 pp.

Westech, Inc. [Western Technology and Engineering]. 1981. The effects of the Tongue River Railroad on terrestrial wildlife. Technical Report for Tongue River Railroad Co.

Westech, Inc. [Western Technology and Engineering]. 1982. Results of Phase one, step one, Little Rockies Project. Tech. Rpt. for Meridan Land and Mineral Co.

Westech, Inc. [Western Technology and Engineering]. 1982. Wildlife reconnaissance, Cypress International Yellowstone Mine. Prepared for Hydrometrics, Inc.

Westech, Inc. [Western Technology and Engineering]. 1987. Valley View Hills: baseline easement report. The Nature Conservancy, Big Sky Field Office, Helena, MT. 44 pp. plus appendices.

Westech, Inc. [Western Technology and Engineering]. No date. Preliminary wildlife reconnaissance, Ruby and Little Ben mine areas, Little Rocky Mountains, Montana. Technical Report for Zortman and Landusky Mining Companies.

Western Ecological Services Co. 1983. Wildlife inventory of the Knowlton known recoverable coal resource area, MT. Prep. for USDI, BLM Cont: No. VA-553-RFP2-1027.

Western Ecological Services Co. 1983. Wildlife inventory of the Southwest Circle known 
recoverable coal resource area, MT. Prepared for U.S. Department of the Interior, BLM. Contract YA-553-RFP2-1027.

Wheeler, G. C. and J. Wheeler. 1966. The amphibians and reptiles of North Dakota. University of North Dakota, Grand Forks. 103 pp.

Wilson, L. D. 1978. COLUBER CONSTRICTOR. Cat. Am. Amph. Rep. 218.1-218.4.

Yoffe, E. 1992. Silence of the frogs. New York Times Magazine 13 Dec 1992:36-39, 64-66, 76. 


\section{APPENDIX 1.}

\section{SITES SURVEYED DURING 1996}

\section{AMPHIBIAN AND REPTILE INVENTORY}


Appendix 1. Sites surveyed during 1996 amphibian and reptile inventory.

\begin{tabular}{|c|c|c|c|c|c|}
\hline Site & Location & & Elevation & Date & Start Time \\
\hline Black Coulee NWR & T34N R25E & S24 NW4 & ---- & 10 Jul 96 & 1730 \\
\hline Bowdoin NWR & T31N R31E & S23 SE4 & 2224 & 20 Jun 96 & 1215 \\
\hline Bowdoin NWR * & T31N R31E & S26 NW 4 & 2220 & 20 Jun 96 & 1310 \\
\hline Bowdoin NWR & T30N R31E & S15 NW4 & 2220 & 20 Jun 96 & 1435 \\
\hline Bowdoin NWR* & T30N R31E & SO 5 SW 4 SE 4 & 2220 & 25 Jul 96 & 0915 \\
\hline Charles M. Russell NWR & T21N R24E & S01 NW4 & 2283 & 13 Jun 96 & 1210 \\
\hline Charles M. Russell NWR & T21N R25E & $\mathrm{S} 02 \mathrm{NW} 4$ & 2296 & 13 Jun 96 & 1415 \\
\hline Charles M. Russe11 NWR (BLM 1 and) & T23N R25E & S26 NW4SW4 & 2953 & 13 Jun 96 & 1630 \\
\hline Charles M. Russell NWR & T21N R24E & S08 NE4 & 2887 & 14 Jun 96 & 1105 \\
\hline Charles M. Russell NWR* & T21N R25E & S06 SW4 & 2461 & 14 Jun 96 & 1550 \\
\hline Charles M. Russell NWR & T21N R37E & S13 NW4 & 2280 & 14 Jun 96 & 2210 \\
\hline Charles M. Russell NWR (BLM land) & T21N R37E & S35 NW4 & 2526 & 15 Jun 96 & 0930 \\
\hline Charles M. Russell NWR & T23N R43E & S21 NE 4 & 2313 & 16 Jun 96 & 1130 \\
\hline Charles M. Russell NWR & T23N R43E & S21 SW 4 & 2330 & 16 Jun 96 & 1530 \\
\hline Charles M. Russell NWR* & T23N R43E & S32 NE4 & 2297 & 16 Jun 96 & 1435 \\
\hline Charles M. Russell NWR* & T21N R43E & $\mathrm{S} 28 \mathrm{NE} 4$ & 2295 & 16 Jun 96 & 2010 \\
\hline Charles M. Russell NWR & T22N R32E & S18 NW 4 & 2297 & 18 Jun 96 & 1630 \\
\hline Creedman Coulee NWR & T37N R15E & S16 SE4SW4 & ---- & 03 Jun 96 & 1520 \\
\hline Lake Thibadeau NWR* & $\mathrm{T} 35 \mathrm{~N}$ R16E & $\mathrm{S} 26,35,36$ & ---- & 03 Jun 96 & 1710 \\
\hline UL Bend NWR & T22N R30E & S23 NW4 & 2392 & 19 Jun 96 & 1030 \\
\hline UL Bend NWR & T22N R29E & S33 SW4 & 2461 & 19 Jun 96 & 1405 \\
\hline Brown WPA & $\mathrm{T} 37 \mathrm{~N} \mathrm{R02W}$ & $\mathrm{S} 34 \mathrm{NW}, \mathrm{S} 35 \mathrm{NW}$ & ---- & 01 Jun 96 & 1915 \\
\hline Dyrdahl WPA & T36N R29E & SO5 SE 4 & 2850 & 11 Jul 96 & 2006 \\
\hline Eoster Creek WPA* & $\mathrm{T} 25 \mathrm{~N} \mathrm{R05W}$ & S06 NW4 & 3930 & 22 Jul 96 & 1630 \\
\hline Holm WPA (Holm Res.) & $\mathrm{T} 36 \mathrm{~N} \cdot \mathrm{R} 18 \mathrm{E}$ & S31 S2 & ---- & 04 Jun 96 & 1950 \\
\hline Holm WPA (McLaren Res.) & T35N R18E & $\mathrm{S} 06 \mathrm{~s} 2$ & ---- & 04 Jun 96 & 1915 \\
\hline Jarina WPA & T28N R09W & S20 NW4NE 4 & 4680 & 31 May 96 & 1620 \\
\hline Jarina WPA* & T28N R09W & S20 SW4NW4 & 4730 & 31 May 96 & 1750 \\
\hline Kingsbury WPA & $\mathrm{T} 21 \mathrm{~N} R 11 \mathrm{E}$ & S17 NW4NE 4 & 3200 & 03 Jun 96 & 1145 \\
\hline
\end{tabular}

* Sites with no herps found during survey 
Appendix 1 (cont.). Sites surveyed during 1996 amphibian and reptile inventory.

\begin{tabular}{|c|c|c|c|c|c|c|c|}
\hline Site & Location & & & Elevation & Date & & Start Time \\
\hline Kingsbury WPA* & $\mathrm{T} 21 \mathrm{~N} \quad \mathrm{R} 11 \mathrm{E}$ & S07 & NE 4 SE 4 & 3270 & $03 \mathrm{Jun}$ & 96 & 1300 \\
\hline Kingsbury WPA & $\mathrm{T} 21 \mathrm{~N} \mathrm{R} 11 \mathrm{E}$ & S18 & SE 4 NW 4 & 3220 & $03 \mathrm{Jun}$ & 96 & 1415 \\
\hline Kingsbury WPA* & $\mathrm{T} 21 \mathrm{~N}$ R11E & S07 & SE 4SE 4 & --- & $03 . J u n$ & 96 & 1530 \\
\hline Korsbeck WPA* (Pond 3) & T28N R27E & S05 & NW 4 & ---- & $04 \mathrm{Jun}$ & 96 & 1825 \\
\hline Korsbeck WPA (Pond 2) & T29N R27E & S31 & SW4 & 2590 & 04 Jun & 96 & 1755 \\
\hline Korsbeck WPA (East Pond) & T29N R27E & S32 & SE 4 NW 4 & 2580 & 04 Jun & 96 & 1515 \\
\hline Korsbeck WPA (Pond 1) & T29N R27E & S31 & E2 & 2770 & 04 Jun & 96 & 1655 \\
\hline Pearse WPA* & T31N R32E & $\mathrm{S} 18$ & SW 4 & 2228 & $25 \mathrm{Jul}$ & 96 & 1215 \\
\hline Webb WPA* & T37N R29E & S30 & NW 4 & 2800 & 11 Jul & 96 & 1930 \\
\hline
\end{tabular}

\footnotetext{
* Sites with no herps found during survey
} 


\section{APPENDIX 2.}

\section{AMPHIBIANS AND REPTILES}

\section{OBSERVED DURING SURVEYS IN 1996}


Appendix 2. Amphibians and reptiles observed on USFWS units during 1996 site surveys. Asterisk means breeding confirmed.

\begin{tabular}{|c|c|c|c|c|c|c|c|c|c|c|}
\hline $\begin{array}{l}\text { Perso } \\
\text { Hrs: } \mathrm{m} \\
\end{array}$ & & $\frac{\text { Total }}{\text { AMT I }}$ & $\begin{array}{l}\text { numbe } \\
\text { BUWO }\end{array}$ & $\begin{array}{l}\mathrm{r} \text { of } \\
\mathrm{BUCO}\end{array}$ & $\frac{\text { adult: }}{\text { PSTR }}$ & $\frac{\mathrm{s} / j u}{\text { RAPI }}$ & $\frac{V \text { of }}{\mathrm{CHPI}}$ & $\frac{\text { each }}{\text { THS I }}$ & $\frac{\text { species }}{\text { THRA }}$ & observed $^{2}$ \\
\hline Black Coulee & $0: 35$ & & & & $0 / \star$ & & $s^{2}$ & & & \\
\hline Bowdoin (Lakeside Unit) & $0: 45$ & & & & & & $1 / 0$ & & & \\
\hline Bowdoin (Goose Is. Unit) & $0: 35$ & & & & $2 / *$ & & $=$ & & & \\
\hline CMR (White Bottoms) & $0: 40$ & & $0 / \star$ & & $10 / 0$ & & $1 / 0$ & & & \\
\hline CMR (Rock Cr. Res.) & $1: 00$ & & & & $0 / \star$ & $1 / 0$ & & & & \\
\hline CMR (BLM Deep Res.) & $0: 40$ & & & & $10 / 0$ & & & & & \\
\hline CMR (Sand Cr. Trail pond) & $0: 50$ & & & & $0 / *$ & & & & & \\
\hline CMR (Hell Cr. Mouth) & $1: 50$ & & $90 / 0$ & $90 / 0$ & $90 / 0$ & & & & & \\
\hline CMR (BLM Hart Cr.) & $2: 00$ & & & $0 / *$ & $1 / *$ & & & & & \\
\hline CMR (N Fork Rock Cr.) & $1: 30$ & $0 / \star$ & & & & & 2 & & & . \\
\hline CMR (pond, Rds 817 \& 836) & $1: 00$ & & $3 / 0$ & & $0 / \star$ & $1 / 0$ & & $1 / 0$ & & \\
\hline CMR (Fourchette Bay) & $0: 30$ & & & & $10 / 0$ & & & & & \\
\hline Creedman Coulee & $0: 40$ & & & & $10 / 0$ & & & $\theta$ & & \\
\hline UL Bend (Valentine Res.) & $1: 00$ & & & & $0 / \star$ & & $1 / 1$ & & $5 / 0$ & \\
\hline UL Bend (Res. Rd 212, 201) & $0: 40$ & & & & $0 / *$ & & & & $4 / 0$ & \\
\hline Brown & $0: 40$ & & & & $50 / 0$ & & & & & \\
\hline Dyrdahl & $0: 30$ & & & & $0 / *$ & & & & & \\
\hline Holm (Holm Res.) & $0: 20$ & & & & $50 / 0$ & & & & & \\
\hline Holm (McLaren Res.) & $0: 30$ & & & & $90 / 0$ & & & & $=1 / 0$ & \\
\hline Jarina ENE of NW Howe Lk & $1: 25$ & & & & $5 / 0$ & & & & & \\
\hline Kingsbury ( $\mathrm{N}$ pond) & $0: 15$ & $0 / \star$ & & & $4 / 0$ & & & & & \\
\hline Kingsbury (NW pond) & $0: 06$ & $0 / \star$ & & & & & & & & \\
\hline Korsbeck (pond 2) & $0: 15$ & & & & $0 / \star$ & & & & & \\
\hline Korsbeck (E pond) & $0: 15$ & & & & $0 / \star$ & & & & & \\
\hline Korsbeck (pond 1) & $0: 45$ & $0 / \star$ & 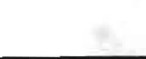 & & $8 / \star$ & & & & & \\
\hline
\end{tabular}

${ }^{1}$ AMTI (Ambystoma tigrinum), BUWO (Bufo woodhousii), BUCO (B. cognatus), PSTR (Pseudacris triseriata), RAPI (Rana pipiens), CI II'I (('hrysemys picta), THSI (Thamnophis sirtalis), THRA (T. radix). 